\title{
Effects of Dew Removal and Mowing Frequency on Fungicide Performance for Dollar Spot Control
}

Tanner C. Delvalle, Peter J. Landschoot, and John E. Kaminski, Department of Crop and Soil Sciences, The Pennsylvania State University, University Park 16802

\begin{abstract}
Delvalle, T. C., Landschoot, P. J., and Kaminski, J. E. 2011. Effects of dew removal and mowing frequency on fungicide performance for dollar spot control. Plant Dis. 95:1427-1432.

Dollar spot (Sclerotinia homoeocarpa) is a severe disease problem on creeping bentgrass (Agrostis stolonifera) fairways. The objective of this study was to evaluate the effects of dew removal and mowing frequency on fungicide performance for dollar spot control. In 2009 and 2010, an experiment involving daily dew removal or no dew removal, mowing frequency $(2,4$, and 6 days week ${ }^{-1}$ ), and fungicides (chlorothalonil, propiconazole, and iprodione) was conducted on creeping bentgrass maintained as a fairway. Daily dew removal resulted in fewer dollar spot infection centers (IC) compared with not removing dew during late summer 2009 and 2010 for all mowing-frequency and fungicide treatments. As mowing frequency increased from 2 to 6 days week $^{-1}$, dollar spot

IC decreased when averaged across all fungicide treatments. For all fungicides, daily dew removal increased the number of days needed to reach a 15 -IC plot $^{-1}$ point of reference when compared with fungicide treatments in which dew was not removed. The number of days required to reach $15 \mathrm{IC}$ varied with fungicide, mowing frequency, and year the test was conducted. Results demonstrate that dollar spot control with fungicides can be extended when daily dew removal is employed and, in some cases, when mowing frequency is increased on dewcovered turf. Benefits of dew-removal practices on dollar spot and fungicide performance can vary with weather conditions, fungicide, threshold level, and possibly other factors.
\end{abstract}

Dollar spot, caused by Sclerotinia homoeocarpa F.T. Benn., is a foliar disease of turfgrass that causes significant damage annually throughout the northeastern United States. This disease is particularly severe on golf course fairways, and can be difficult to control due to environmental factors and cultural practices favoring disease epidemics. Although dollar spot can be controlled with fungicides, golf course managers often try to limit fungicide use on fairways due to economic, environmental, and fungicide-resistance concerns.

Certain cultural practices are important in suppressing dollar spot and are often used by golf course managers as part of an integrated disease management program. The practices of removing leaf surface moisture, mowing, irrigation, nitrogen fertilization, and use of plant growth regulators have been shown to influence the severity of dollar spot $(2,3,7,8,14)$. Most studies dealing with the effects of cultural practices on dollar spot have been conducted without fungicides. Because many golf course managers use cultural practices in conjunction with fungicides in their dollar spot control programs, knowledge of how these practices influence fungicide performance would be beneficial in developing a more effective integrated disease management program.

Periodic removal of dew from leaf surfaces is an important means of suppressing dollar spot symptoms. Dew on turf canopies is composed of condensate and plant-generated moisture, including wound exudates and guttation fluid containing amino acids, sugars, potassium, and other compounds. Williams et al. (14) reported up to an $81 \%$ reduction in dollar spot severity by removing dew through mowing and by using a mower with reels disengaged. In a later study, Ellram et al. (3) showed that removing dew on a daily basis was more effective in reducing dollar spot than dew removal on alternate days. Although dew removal plays an important role in suppressing dollar spot, little research has been conducted to establish the role of dew removal on fungicide performance. In one of the few studies dealing with the influence of dew removal on

Corresponding author: P. J. Landschoot, E-mail: pj11 @psu.edu

Accepted for publication 10 June 2011.

doi:10.1094/PDIS-12-10-0941

(C) 2011 The American Phytopathological Society fungicide performance, McDonald et al. (9) demonstrated that chlorothalonil applied to a turf canopy following early-morning dew removal only occasionally provided better dollar spot control than applications on turf with dew present.

To date, little research has been performed on the influence of mowing practices on fungicide performance. In a study designed to examine the effect of mowing frequency independent of dew removal on seasonal fungicide use, Putman (11) concluded that mowing frequency did not impact fungicide performance. The author speculated that the influence of fungicide-protected leaf tissue removal on dollar spot control was minimal due to the short duration of fungicide residual in turfgrass. In the absence of fungicides, mowing frequency impacted dollar spot severity on 5 of 17 dates, with dollar spot severity lowest on plots mowed 2 days week $^{-1}$ versus plots mowed 4 or 6 days week ${ }^{-1}$. Putman (11) suggested that the increase in dollar spot with more frequent mowing may be due to a weakening of host defenses and altering plant growth habit, thereby creating an environment more favorable for disease-causing activities of the pathogen.

A recent study examining the effects of simulated rain and mowing timing on fungicide performance showed that mowing in the morning versus afternoon mowing significantly reduced dollar spot across all fungicide treatments (10). The authors reported 54 to $65 \%$ fewer infection centers (IC) in plots mowed in the morning compared with plots mowed in the afternoon when averaged across chlorothalonil, propiconazole, boscalid, and iprodione treatments. Pigati et al. (10) concluded that morning mowing not only reduces leaf wetness duration but also physically removes or displaces $S$. homoeocarpa mycelia. The authors also suggested dollar spot could be reduced by removing mycelia in infected leaf tissue through collection of clippings in mowing baskets.

The objective of this research was to determine whether daily dew removal in conjunction with mowing frequency $(2,4$, or 6 days $w^{-} \mathrm{k}^{-1}$ ) on turfgrass managed as a golf course fairway improves fungicide performance in relation to dollar spot control.

\section{Materials and Methods}

This experiment was conducted at the Joseph Valentine Turfgrass Research Center, University Park, PA on three separate occasions (test 1, late summer 2009; test 2, late spring 2010; and test 3, late summer 2010) in areas adjacent to one another. The turf was a 7-year-old mixed stand of 'Penneagle' creeping bentgrass 
(Agrostis stolonifera L.) (approximately 80\%) and annual bluegrass (Poa annua L.) (approximately 20\%) maintained as a golf course fairway. The soil was a Hagerstown silt loam (fine, mixed, mesic, Typic Hapludalf) with a pH of 6.6, Mehlich-3 P at $224 \mathrm{~kg}$ $\mathrm{ha}^{-1}$, exchangeable $\mathrm{K}$ at $0.16 \mathrm{cmol} \mathrm{kg} \mathrm{kg}^{-1}$ of soil, and a CEC of 11.1 $\mathrm{cmol}_{\mathrm{c}} \mathrm{kg}^{-1}$ of soil. Prior to the initiation of the experiment, the turf was mowed 3 days week ${ }^{-1}$ at a bench setting of $1.3 \mathrm{~cm}$ with a Toro ReelMaster 5400-D fairway mower (The Toro Company, Bloomington, MN). Clippings were collected in baskets and removed from the site. The site was fertilized using $\mathrm{N}$ at $18 \mathrm{~kg} \mathrm{ha}^{-1}$ as urea (46-0-0) in April of 2009. Clorothalonil (Daconil Ultrex 82.5 WDG; Syngenta Crop Protection, Greensboro, NC) was applied to the site at $4.5 \mathrm{~kg}$ a.i. $\mathrm{ha}^{-1}$ on three occasions during June and July 2009 to control dollar spot prior to initiation of test 1 on 21 August 2009. Following termination of test 1 in September, the site was aerated, verticut, and fertilized with $\mathrm{N}$ at $49 \mathrm{~kg} \mathrm{ha}^{-1}$ from urea, and was mowed 3 days week ${ }^{-1}$ with the Toro ReelMaster 5400-D until the end of the growing season. In 2010, the experiment site was fertilized with $\mathrm{N}$ at $18 \mathrm{~kg} \mathrm{ha}^{-1}$ as urea (46-0-0) in April. No fungicides were applied to the site prior to the initiation of test 2 in May of 2010, and chlorothalonil was applied at $4.5 \mathrm{~kg}$ a.i. ha ${ }^{-1}$ at 10-day intervals until the initiation of test 3 in August of 2010.

The experiment was a two-by-three-by-four factorial arranged as a strip-split-plot design with three replications. The main plots included two dew-removal treatments (dew removed 7 days week $^{-1}$ or no dew removed), strips were three mowing-frequency treatments $\left(2,4\right.$, and 6 days week $\left.^{-1}\right)$, and subplots included four fungicide treatments. Dew was removed 7 days week $^{-1}$ by driving the Toro ReelMaster 5400-D across the dew-removal treatment plots prior to mowing, with mowing units lowered and resting on the turf but with reels disengaged.

Mowing schedules were Monday, Tuesday, Wednesday, Thursday, Friday, and Saturday for the 6-day-week ${ }^{-1}$ mowing treatment; Monday, Wednesday, Friday, and Saturday for the 4-day-week ${ }^{-1}$ treatment; and Tuesday and Friday for the 2-day-week ${ }^{-1}$ treatment. Each mowing-frequency treatment plot was 3.7 by $3.1 \mathrm{~m}$. All mowing events were performed between 0700 and $0800 \mathrm{~h}$ using the Toro ReelMaster 5400-D fairway mower adjusted to a bench setting of $1.3 \mathrm{~cm}$. Clippings were collected in baskets and removed from the site.

Fungicide treatments were applied once at the initiation of each of the three tests. Treatments included chlorothalonil (Daconil Ultrex 82.5 WDG, ) applied at $8.2 \mathrm{~kg}$ a.i. $\mathrm{ha}^{-1}$; propiconazole (ProPensity 1.3 ME; Sipcam Agro USA, Inc., Roswell, GA) applied at $0.7 \mathrm{~kg}$ a.i. ha ${ }^{-1}$; iprodione (Chipco 26 GT, Bayer Environmental
Science, Montvale, NJ) applied at $2.1 \mathrm{~kg}$ a.i. $\mathrm{ha}^{-1}$; and a nontreated control. Subplots for fungicides treatments were 0.9 by $3.1 \mathrm{~m}$. Fungicide treatments were applied with a $\mathrm{CO}_{2}$-pressurized (276 $\mathrm{kPa}$ ) bicycle sprayer equipped with a single boom fitted with a 9504E flat-fan nozzle (TeeJet Technologies, Wheaton, IL) calibrated to deliver water at 407 liters ha ${ }^{-1}$.

For each of the three tests, the entire experiment site was mowed with the Toro ReelMaster 5400-D fairway mower approximately 1 $\mathrm{h}$ prior to fungicide application. Fungicide treatments were applied on 21 August 2009, 28 May 2010, and 24 August 2010. Dollar spot symptoms were not visible on the dates fungicides were applied. Each test area was mowed 1 day after fungicide treatments were applied. Dew-removal treatments commenced 2 days following fungicide application, and mowing-frequency treatments began 3 days following fungicide application.

The quantity of dew was assessed at the time of dew removal on each day of the three test periods using a method devised by Williams et al. (14). This procedure involved placing a $0.31-$ by- $0.31-\mathrm{m}$ wooden frame on the turf, and using dry, preweighed tissue papers to absorb dew within the frame. Individual tissue papers were weighed immediately to determine the amount of liquid absorbed within the frame, and converted to liters of dew per hectare.

Dollar spot developed naturally in all tests, and was assessed by counting the number of IC per plot. Dollar spot was assessed three times in test $1(1,10$, and 17 September 2009), eight times in test 2 (7, 10, 14, 17, 21, 23, and 28 June and 1 July 2010), and seven times in test $3(4,8,11,16,18,22$, and 25 September 2010). Each test concluded when individual IC could no longer be distinguished in the most severely affected plots. Tests were terminated on 17 September 2009, 1 July 2010, and 25 September 2010.

A total of $15 \mathrm{IC}$ within a $2.8-\mathrm{m}^{2}$ plot area was selected as a point of reference for comparing fungicide responses to dew-removal and mowing-frequency treatments. No universally accepted dollar spot threshold level exists for creeping bentgrass fairways in the northeastern United States, and some golf course managers may use higher or lower thresholds depending on their tolerance for disease damage and fungicide budget.

Dollar spot IC data from each rating date and area under the disease progress curve (AUDPC) values for each test were subjected to analysis of variance (ANOVA). Additionally, preplanned contrasts were conducted on data which excluded plots not receiving fungicide treatments. All statistical analysis was performed using PROC MIXED of SAS (v. 9.1; SAS Institute, Cary, NC). Data were $\log$ transformed prior to analysis to conform to assumptions for ANOVA. Multiple comparison tests were performed using
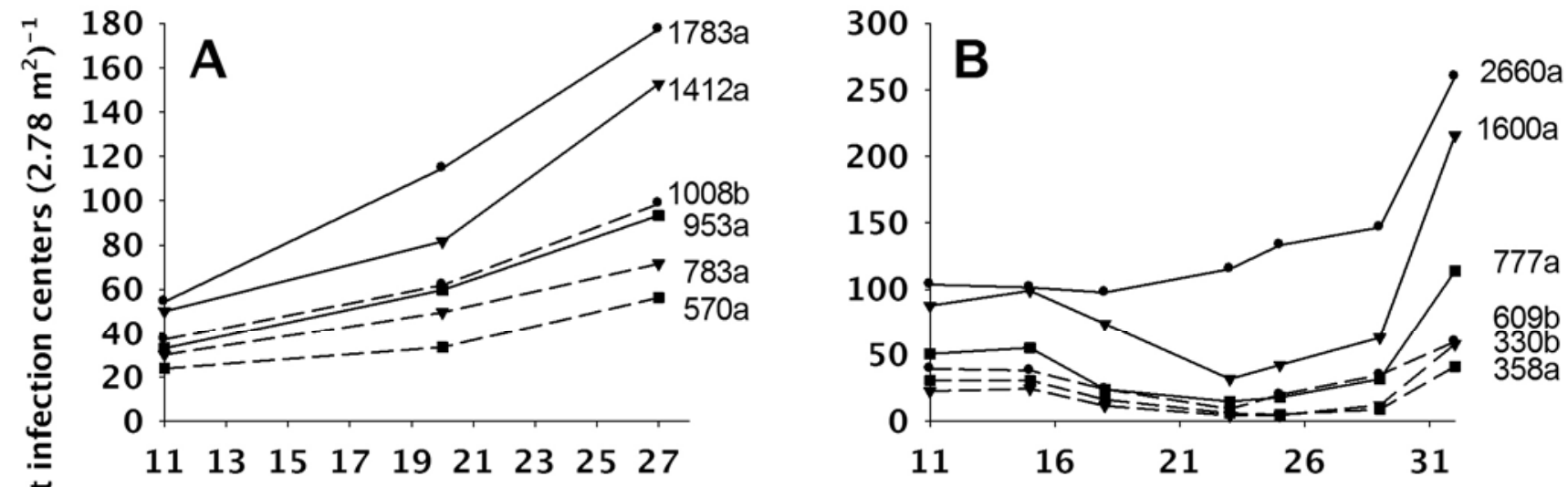

\section{Days after application}
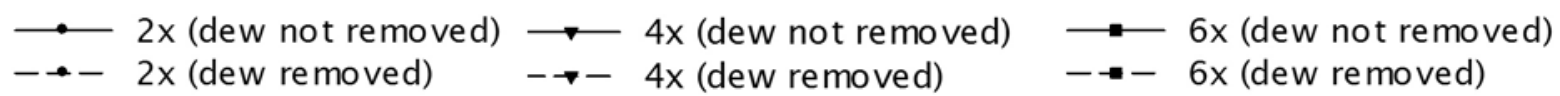

Fig. 1. Dollar spot progression within plots in which fungicides were not applied in A, late summer 2009 and $\mathbf{B}$, late summer 2010 . Area under disease progress curve values with different letters are significantly different at $P \leq 0.05$ for dew-removal treatments within each mowing frequency. 
Tukey's honestly significant difference test and means were separated at $P \leq 0.05$.

\section{Results}

The nature of dollar spot disease epidemics differed among the three test periods. During late summer of 2009 (test 1), dollar spot IC increased from 0 on the day of treatment application to between 21 and 58 IC for the non-fungicide treatments during the first 11 days of the epidemic. Over the next 16 days, dollar spot IC increased steadily to between 58 and 177 IC for these treatments (Fig. 1A). In test 1, the AUDPC value for the non-fungicide-treated 2-day-week ${ }^{-1}$ mowing frequency with dew not removed was higher than for the 2-day-week ${ }^{-1}$ treatment in which dew was removed. No differences were detected with respect to dew removal for the 4- and 6-day-week ${ }^{-1}$ mowing treatments that were not treated with fungicides (Fig. 1A). Dollar spot developed slowly during late spring of 2010 (test 2) and never reached levels found in late summer 2009 and 2010 (data not shown). The dollar spot epidemic during late summer 2010 (test 3) began with 0 IC on the day treatments were applied and progressed to between 21 and 102 IC for the non-fungicide treatments during the first 11 days of the epidemic. Over the next 3 days (12 to 15 days after application), dollar spot IC increased slightly or remained the same, followed by a decline from 15 to 25 days after application. Plots mowed 2 days week $^{-1}$ with dew not removed were the exception, showing an increase in IC over this 10-day period. From 25 to 32 days after application, all of the non-fungicide-treated plots showed another increase in IC for all treatments (Fig. 1B). In test 3, the AUDPC values for the 2- and 4-day-wee ${ }^{-1}$ mowing-frequency treatments with dew not removed were higher than those for the 2- and 4-dayweek $^{-1}$ mowing-frequency treatments in which dew was removed. No difference in AUDPC was found between the 6-day-week ${ }^{-1}$ dew-removal treatments in test 3 (Fig. 1B).

Dew measurements revealed greater mean daily dew volumes in the late summer test periods in 2009 and 2010 versus the late spring test period in 2010 . When dew was present in the late summers of 2009 and 2010, mean daily dew volume was 1,605 and 1,788 liters $\mathrm{ha}^{-1}$, respectively. In late spring 2010, mean daily dew volume was 950 liters ha ${ }^{-1}$ when dew was present.

ANOVA of all dollar spot IC AUDPC data and preplanned contrasts with non-fungicide-treated controls omitted are presented in Table 1. Due to the lack of dollar spot suppression in nontreated controls and the particular interest in how dew-removal and mow- ing-frequency treatments influenced fungicide performance, only contrasts with nontreated controls omitted are discussed.

Preplanned contrasts of dew removal revealed that the effect of daily dew removal was significant for AUDPC data in test 1 and test 3 but not for test 2 (Table 1). Dollar spot IC were more numerous in plots where dew was not removed compared with plots in which dew was removed for all mowing frequencies and fungicide treatments in test 1 and test 3 (Fig. 2).

Two mowing-frequency preplanned contrasts are presented in Table 1. The first mowing contrast (Mow) includes both dew-removal treatments (dew removed daily and dew not removed), whereas the second mowing contrast (Mow-Daily Dew Removal) includes only those plots in which dew was removed daily. The preplanned contrast Mow shows a significant mowing effect for AUDPC data in test 1 and test 3 but not in test 2 . In test 1 , plots mowed 2 days week ${ }^{-1}$ had more dollar spot IC than those mowed 6 days week ${ }^{-1}$ (Table 2). However, no differences in dollar spot IC were observed between plots mowed 2 and 4 days week $^{-1}$ or 4 and 6 days week ${ }^{-1}$. In test 3 , a greater number of dollar spot IC were found in plots mowed 2 days week ${ }^{-1}$ when compared with those mowed 4 or 6 days week ${ }^{-1}$ but no differences were detected between the 4- and 6-day-week ${ }^{-1}$ treatments (Table 2).

The Mow-Daily Dew Removal contrast, in which only the daily dew-removal treatment was included in the AUDPC data analysis, indicates a significant mowing effect in test 3. However, when data from test 3 were subjected to the Tukey's honestly significant difference test, no differences among mowing treatments were detected (data not shown).

ANOVA indicates a significant fungicide effect in all three tests (Table 1). The fact that iprodione-treated plots yielded fewer IC in all three tests when compared with plots treated with chlorothalonil and propiconazole was expected and, thus, was of minor interest. Chlorothalonil is a contact fungicide with a relatively short duration of dollar spot control at the rate used in this study, and generally showed a greater number of IC compared with iprodione and propiconazole as epidemics progressed. S. homoeocarpa isolates from the Joseph Valentine Turfgrass Research Center are known to have reduced sensitivity to propiconazole, and this was reflected in greater numbers of IC in propiconazole-treated plots when compared with those treated with iprodione. Data showing comparisons of fungicides alone are not presented.

The number of days required for each fungicide treatment to reach 15 IC $2.8 \mathrm{~m}^{2-1}$ varied with dew-removal and mowing-fre-

Table 1. Analysis of variance of $\log _{10}$-transformed area under disease progress curve (AUDPC) data from late summer 2009, late spring 2010, and late summer $2010^{\mathrm{u}}$

\begin{tabular}{|c|c|c|c|c|c|c|c|}
\hline \multirow[b]{2}{*}{ Source of variation } & \multirow[b]{2}{*}{ df } & \multicolumn{2}{|c|}{ Late summer 2009 (test 1) } & \multicolumn{2}{|c|}{ Late spring 2010 (test 2) } & \multicolumn{2}{|c|}{ Late summer 2010 (test 3) } \\
\hline & & $F$ value & $P>F$ & $F$ value & $P>F$ & $F$ value & $P>F$ \\
\hline Dew removal $(\text { Dew })^{\mathrm{v}}$ & 1 & 58.66 & 0.0003 & 12.72 & 0.0704 & 105.02 & $<0.0001$ \\
\hline Mowing frequency (Mow)w & 2 & 5.81 & 0.0655 & 3.37 & 0.1387 & 20.60 & 0.0003 \\
\hline Fungicide $^{\mathrm{x}}$ & 3 & 65.17 & $<0.0001$ & 88.19 & $<0.0001$ & 175.95 & $<0.0001$ \\
\hline Mow $\times$ Dew & 2 & 0.79 & 0.4977 & 0.81 & 0.5068 & 1.41 & 0.2898 \\
\hline Mow $\times$ Fungicide & 6 & 1.12 & 0.3693 & 2.03 & 0.0863 & 0.26 & 0.9540 \\
\hline Dew $\times$ Fungicide & 3 & 3.89 & 0.0166 & 1.77 & 0.1695 & 0.87 & 0.4669 \\
\hline Mow $\times$ Dew $\times$ Fungicide & 6 & 0.34 & 0.9104 & 1.11 & 0.3754 & 0.52 & 0.7886 \\
\hline \multicolumn{8}{|l|}{ Contrast $^{\mathrm{y}}$} \\
\hline Dew & 1 & 63.32 & 0.0002 & 11.47 & 0.0772 & 92.52 & $<0.0001$ \\
\hline Mow & 2 & 6.96 & 0.0499 & 3.38 & 0.1382 & 17.90 & 0.0005 \\
\hline Mow-Daily Dew Removal ${ }^{z}$ & 2 & 4.37 & 0.0985 & 1.89 & 0.2647 & 4.63 & 0.0378 \\
\hline Fungicide & 2 & 37.19 & $<0.0001$ & 52.72 & $<0.0001$ & 54.14 & $<0.0001$ \\
\hline Mow $\times$ Dew & 2 & 1.10 & 0.3922 & 1.96 & 0.2552 & 0.70 & 0.5196 \\
\hline Mow $\times$ Fungicide & 4 & 0.51 & 0.7279 & 2.23 & 0.0954 & 0.17 & 0.9524 \\
\hline Dew $\times$ Fungicide & 2 & 2.86 & 0.0767 & 1.38 & 0.2704 & 0.41 & 0.6635 \\
\hline Mow $\times$ Dew $\times$ Fungicide & 4 & 0.19 & 0.9392 & 0.22 & 0.9272 & 0.45 & 0.7715 \\
\hline
\end{tabular}

" AUDPC values were based on the number of dollar spot infection centers per plot.

${ }^{v}$ Dew-removal treatments were performed using a Toro 5400 fairway reel mower with reels disengaged.

${ }^{\mathrm{w}}$ Mowing treatments were performed by mowing plots 2, 4, or 6 days week ${ }^{-1}$ using a Toro 5400 fairway reel mower set to a height of $1.3 \mathrm{~cm}$.

${ }^{\mathrm{x}}$ Fungicides included chlorothalonil $\left(8.2 \mathrm{~kg}\right.$ a.i. ha $\left.{ }^{-1}\right)$, iprodione $\left(2.1 \mathrm{~kg}\right.$ a.i. ha $\left.{ }^{-1}\right)$, propiconazole $\left(0.7 \mathrm{~kg} \mathrm{ai.} \mathrm{ha}^{-1}\right)$, and a nontreated control.

y Contrasts excluded all plots in which fungicides were not applied.

${ }^{\mathrm{z}}$ Contrast excluded all plots in which fungicides were not applied and treatment with no dew removed. 
quency treatments as well as the test period. Daily dew removal increased the number of days to reach 15 IC, regardless of fungicide (Fig. 2). During test 1, dew removal in iprodione-treated plots provided 6 (2-day-week ${ }^{-1}$ mowing frequency) and 10 (4-day-week ${ }^{-1}$ mowing frequency) additional days to reach 15 IC compared with plots in which dew was not removed. In the 6-day-week ${ }^{-1}$ mowingfrequency treatment in test 1 and all mowing-frequency treatments in test 3, iprodione applied to plots in which dew was removed never reached 15 IC when the studies were concluded 27 (test 1) and 31 days (test 3 ) after treatment applications (Fig. 2).

For propiconazole-treated plots in test 1 , dew removal provided one (2-day-week ${ }^{-1}$ mowing frequency), nine (4-day-week ${ }^{-1}$ mowing frequency), and four (6-day-wee ${ }^{-1}$ mowing frequency) additional days to reach 15 IC compared with propiconazole-treated plots in which dew was not removed. In test 3, dew removal in propiconazole-treated plots allowed five (2-day-week ${ }^{-1}$ mowing frequency) additional days to reach 15 IC. Dollar spot IC never
Table 2. Area under the disease progress curve (AUDPC) values for each mowing frequency treatment averaged across all fungicide treatments

\begin{tabular}{llc}
\hline & \multicolumn{2}{c}{ AUDPC $^{\mathbf{y}}$} \\
\cline { 2 - 3 } Mowing frequency $^{\mathbf{z}}$ & Test $\mathbf{1}$ & Test 3 \\
\hline 2 days week $^{-1}$ & $630 \mathrm{a}$ & $184 \mathrm{a}$ \\
4 days week $^{-1}$ & $509 \mathrm{ab}$ & $79 \mathrm{~b}$ \\
d days week $^{-1}$ & $261 \mathrm{~b}$ & $54 \mathrm{~b}$ \\
\hline
\end{tabular}

${ }^{y}$ AUDPC values were based on the number of dollar spot infection centers per plot and were collected during late summer 2009 (test 1) and late summer 2010 (test 2). Values followed by the same letter are not significantly different according to Tukey's honestly significant difference test $(P \leq 0.05)$. Data from nontreated controls were omitted from the analysis.

${ }^{\mathrm{z}}$ Mowing frequency treatments were performed by mowing plots 2, 4, or 6 days week $^{-1}$ using a Toro 5400 fairway reel mower set to a height of 1.3 $\mathrm{cm}$.

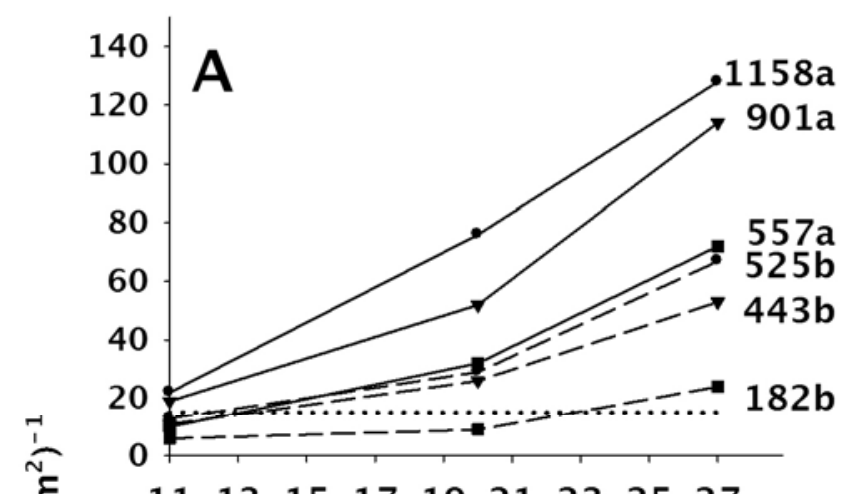

$\begin{array}{lllllllll}11 & 13 & 15 & 17 & 19 & 21 & 23 & 25 & 27\end{array}$

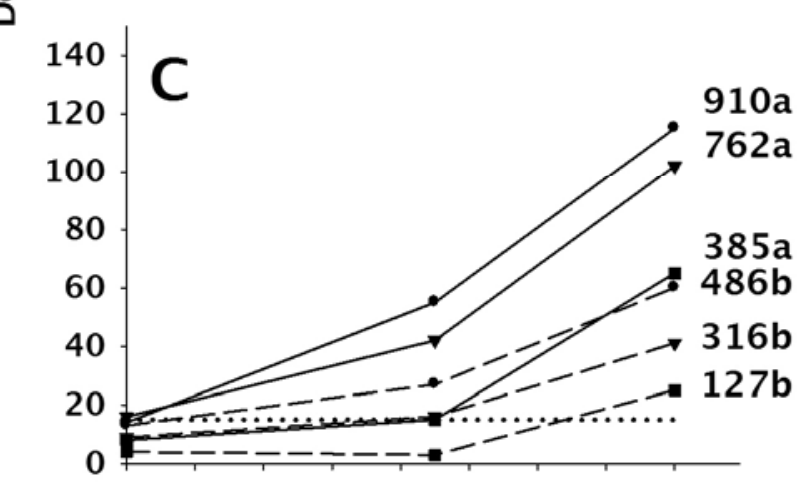

$\begin{array}{lllllllll}11 & 13 & 15 & 17 & 19 & 21 & 23 & 25 & 27\end{array}$
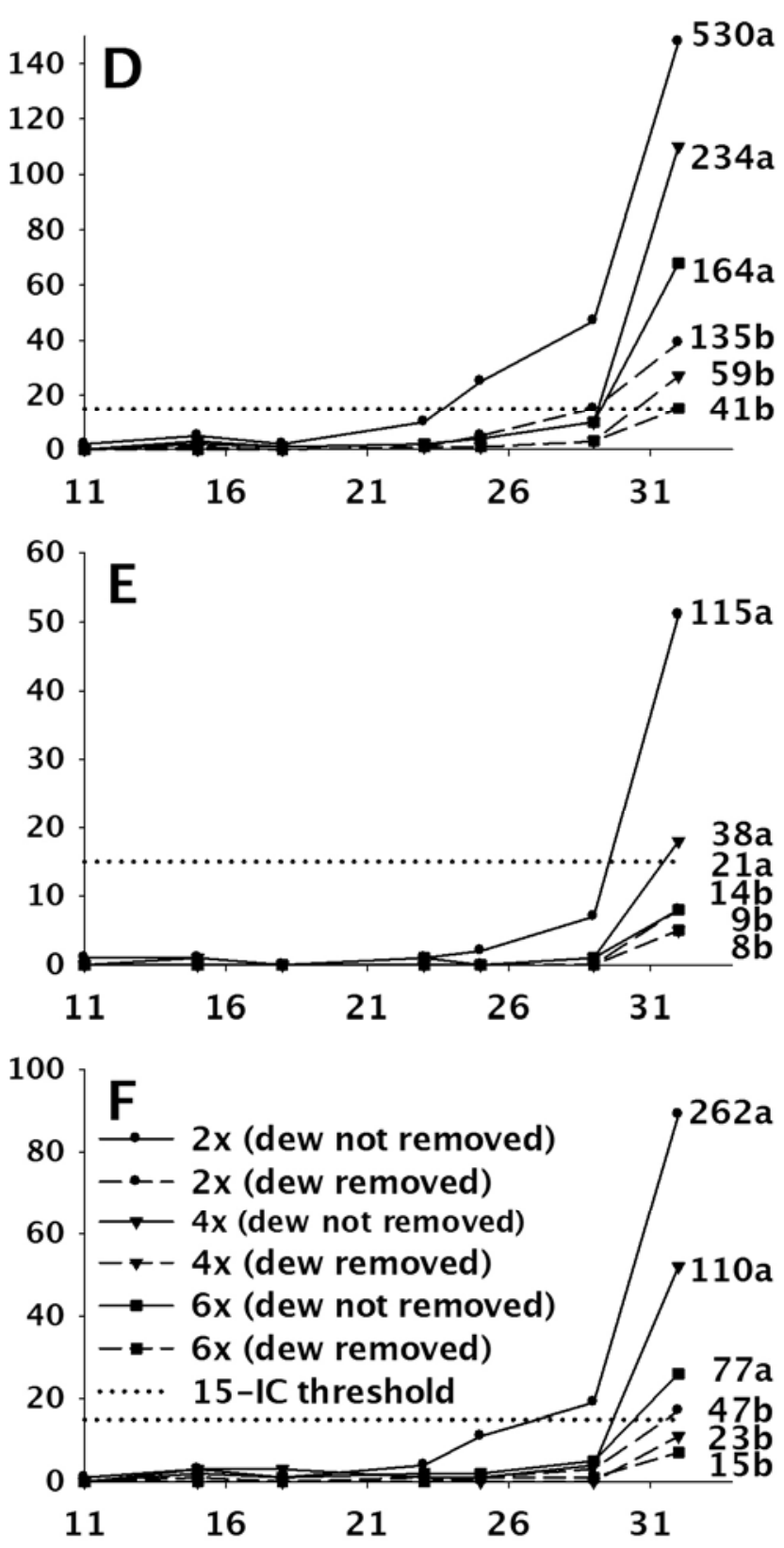

Days after application

Fig. 2. Effect of daily dew-removal treatment and fungicide (A and D, chlorothalonil; $\mathbf{B}$ and $\mathbf{E}$, iprodione; and $\mathbf{C}$ and $\mathbf{F}$, propiconazole) on dollar spot infection centers for the 2-, 4-, and 6-day-week ${ }^{-1}$ mowing-frequency treatments in A-C, late summer 2009 and $\mathbf{D}-\mathbf{F}$, late summer 2010. Area under disease progress curve values with different letters are significantly different at $P \leq 0.05$ for dew-removal treatments within each mowing frequency. Data from nontreated controls were omitted from the analysis. 
reached 15 IC in plots in which dew was removed when mowed 4 or 6 days week ${ }^{-1}$ during test 3 (Fig. 2).

In test 1 , chlorothalonil applied to plots where dew was removed resulted in one (2-day-week ${ }^{-1}$ mowing frequency), three (4-dayweek $^{-1}$ mowing frequency), and 10 (6-day-wee ${ }^{-1}$ mowing frequency) additional days to reach 15 IC when compared with chlorothalonil-treated plots in which dew was not removed. During test 3, chlorothalonil-treated plots in which dew was removed provided five (2-day-week ${ }^{-1}$ mowing frequency), two (4-day-week ${ }^{-1}$ mowing frequency), and three (6-day-week ${ }^{-1}$ mowing frequency) additional days to reach 15 IC compared with chlorothaloniltreated plots in which dew was not removed (Fig. 2).

\section{Discussion}

Disease data collected during the late summers of 2009 and 2010 indicated that daily dew removal and increased mowing frequency from 2 to 6 days week ${ }^{-1}$ on dew-covered turf resulted in a reduction of dollar spot and improvement in the performance of all three fungicides used in this study. Daily dew removal during late spring 2010 did not show a significant influence on dollar spot IC. Although unclear, this may have been due to the lower mean daily dew volume on turf foliage (950 liters ha ${ }^{-1}$ ) during this test period when compared with the late summer test periods of $2009(1,605$ liters $\left.\mathrm{ha}^{-1}\right)$ and $2010\left(1,788\right.$ liters $\left.\mathrm{ha}^{-1}\right)$. The higher dew volumes in late summer may have increased dollar spot by extending the leaf wetness period and accentuating differences between dew-removal treatments for fungicide-treated turf (5). Dew measurements in this study were within a similar range as reported by Williams et al. (13) and McDonald et al. (9). Other factors, such as temperature and humidity, may also have influenced the results.

Daily dew removal in late summer reduced dollar spot regardless of mowing-frequency or fungicide treatment. When plots were mowed 4 days week ${ }^{-1}$ in late summer 2009, dollar spot based on AUDPC data for dew-removal treatments was reduced $51 \%$ for chlorothalonil, $59 \%$ for propiconazole, and $78 \%$ for iprodione when compared with plots in which dew was not removed. The percent reduction of dollar spot severity for the 2-day-week ${ }^{-1}$ mowing frequency during the same period was $55 \%$ for chlorothalonil, $47 \%$ for propiconazole, and $62 \%$ for iprodione. Within plots mowed 6 days week ${ }^{-1}$, dollar spot was reduced by a total of 67,67 , and $81 \%$ for the fungicides chlorothalonil, propiconazole, and iprodione, respectively. Although these percentages include severity data that may be above the threshold levels used by some golf course managers, they illustrate the beneficial effects of dew removal on reducing dollar spot in fungicide-treated plots. Pigati et al. (10) noted similar dollar spot reductions for chlorothalonil (64 to $67 \%$ ), propiconazole (50 to $54 \%$ ), and iprodione (39 to $70 \%$ ) in morning-mowed versus afternoon-mowed turf in which dew was not removed.

Reductions of dollar spot in fungicide-treated plots resulting from daily dew removal in this study reflects findings of previous studies in which dollar spot was reduced when leaf surface moisture was displaced by various early-morning dew-removal methods $(3,12,14)$. Dew on fairway turf canopies comprises condensate and up to $33 \%$ plant-generated moisture. Plant-generated moisture is composed of wound exudates and guttation fluid containing amino acids, sugars, potassium, and other compounds that can enhance growth of certain fungal pathogens $(1,4,13)$. Dew on plant surfaces aids in hyphal growth, turgidity, and adherence to host surfaces; host penetration and infection; as well as pathogen dispersal $(1,6)$. Presumably, interruption of leaf moisture duration via dew removal or mowing curtails important pathogen activities responsible for the increase in dollar spot severity.

Although increased mowing frequency on fairway turf has been shown to reduce dollar spot severity, its role on fungicide efficacy is not well understood $(3,11)$. In a recent study on the impact of mowing frequency on fungicide performance, Putman (11) found that mowing frequency on dry turf with clippings collected did not influence seasonal fungicide use. The author suggested that removing fungicide-protected leaf tissue had minimal impact on dollar spot control due to the short duration of fungicide residual in turfgrass.

In the current study, as mowing frequency increased from 2 to 6 days week $^{-1}$, dollar spot severity decreased in late summer 2009 and 2010, regardless of supplemental dew removal. However, when mowing frequency data were analyzed only for treatments in which dew was removed every day, differences were not detected according to Tukey's honestly significant difference test. Thus, when data from dew-covered turf was removed from the analyses, mowing frequency had little impact on dollar spot control from each fungicide. These results agree with Putman's finding that fungicide control is not associated with mowing frequency when leaf wetness is not a factor (11). Results also suggest that the influence of increased mowing frequency on reductions in dollar spot on fungicide-treated turf is primarily related to dew removal. Pigati et al. (10) suggested that reduced leaf wetness and physical disruption or removal of $S$. homoeocarpa mycelia associated with morning mowing are responsible for the improved performance of fungicides for dollar spot control.

Golf course managers may benefit from knowing how long fungicides would last when combined with dew removal practices or increasing mowing frequency. In the current study, the additional days needed to reach 15 IC for a fungicide treatment subjected to dew removal varied with mowing frequency, fungicide, and season. Using a mowing frequency of 4 days week $^{-1}$ in late summer of 2009, iprodione-treated plots receiving daily dew removal provided 10 additional days to reach 15 IC when compared with iprodione-treated plots not receiving daily dew removal. During the same period, plots treated with iprodione and in which dew was removed provided six additional days to reach 15 IC with the 2-day-week ${ }^{-1}$ mowing frequency. By comparison, propiconazole provided nine additional days to reach 15 IC under the 4-dayweek $^{-1}$ mowing-frequency treatment but only one additional day under the 2-day-week ${ }^{-1}$ mowing-frequency treatment in late summer 2009. The 2009 chlorothalonil 2- and 4-day-week ${ }^{-1}$ mowingfrequency treatments provided very few additional days of acceptable dollar spot suppression, perhaps due to the short duration of control with this contact-type fungicide.

The 2009 and 2010 late-summer test periods produced different dollar spot epidemics; thus, the number of days needed to reach 15 IC varied between the two test periods. During late summer 2009, propiconazole-treated plots subjected to daily dew removal and mowing 2 days week ${ }^{-1}$ provided one additional day to reach 15 IC compared with propiconazole-treated plots in which dew was not removed. However, in 2010, the same propiconazole treatment provided five additional days to reach 15 IC. The discrepancy in results between 2009 and 2010 may have been due to an increased rate of dollar spot development early in the 2009 test, limiting the beneficial effects of repeated dew-removal episodes. During late summer of 2009, chlorothalonil-treated plots that were subjected to dew removal and mowing 6 days week $^{-1}$ provided 10 additional days to reach $15 \mathrm{IC}$ whereas the same treatment provided only five additional days to reach 15 IC in late summer 2010. In this case, a rapid increase in disease severity late in the 2010 test may have overwhelmed some of the benefits of mowing and dew removal. Also, by the time the increase in disease severity occurred, the effects of chlorothalonil had likely diminished. Determination of the number of days that fungicide control could be extended was complicated by the fact that the 15-IC point of reference was not reached by the end of each study for all treatments, especially in 2010.

The 15-IC point of reference used in the current study was for the purpose of comparing selected treatments. A higher point of reference for dollar spot severity would have shown longer periods of symptom suppression when dew was removed for some fungicides and mowing-frequency treatments. If a lower point of reference was used, the number of days until dollar spot IC reached this level would have been less for some treatments. Golf course managers establish different threshold levels for unacceptable dollar spot damage for a variety of reasons, and no universally accepted 
threshold is applicable to all golf courses. Although a high threshold level for dollar spot damage may result in an increase in days between fungicide applications, damage may be unacceptable to golfers. Additionally, higher thresholds likely would result in an increase in S. homoeocarpa inoculum and might necessitate higher fungicide rates to achieve acceptable control with subsequent applications. Lower threshold levels would likely provide fewer days of dollar spot suppression when fungicides were used in conjunction with dew removal. However, disease epidemics may be less damaging and subsequent fungicide applications may require lower rates because of reduced inoculum.

The benefits of reduced dollar spot severity and improved fungicide performance associated with dew removal may also depend on the thoroughness of the dew-removal method. The reduction in dollar spot from dew removal in the current study may have been partially influenced by the removal method. Use of reel mower units with reels disengaged provided extremely effective removal of leaf moisture and would probably be more effective at suppressing dollar spot than more common methods such as dragging a hose or rope over dew-covered turf. Although a direct comparison of mower units with reels disengaged and other dew-removal methods was not performed in the current study, Williams and Powell (12) found that removal of dew by rolling or mowing was significantly better at displacing leaf moisture compared with a surfactant, dragging a hose, or syringing. However, all methods used by Williams and Powell (12) dramatically reduced dollar spot severity when compared with treatments in which dew was not removed.

Whether the cost of dew-removal programs can offset savings associated with fewer fungicide applications would depend on many factors, including the fungicide, mowing frequency, nature of the epidemic, threshold level, and possibly the dew-removal method. Although results of this study do not provide enough information to establish a definite economic benefit from dewremoval practices, they do suggest that dollar spot severity may be reduced when daily dew removal is practiced on fungicide-treated turf. Regardless of any economic impact associated with dew removal, turfgrass managers having to deal with fungicide use restrictions may find this cultural practice beneficial. Results also confirm findings of previous studies that no detrimental effects on fungicide performance are associated with increasing mowing frequency.

\section{Acknowledgments}

A portion of this study was funded by The Pennsylvania Turfgrass Council. We thank M. Risius for assistance with statistics, D. Livingston for help with mower and plot maintenance, and W. Uddin for advice in setting up experiments.

\section{Literature Cited}

1. Agrios, G. N. 2005. Plant Pathology, 5th ed. Elsevier Academic Press, San Diego, CA.

2. Burpee, L. L., Green, D. E., and Stephens, S. L. 1996. Interactive effects of plant growth regulators and fungicides on epidemics of dollar spot in creeping bentgrass. Plant Dis. 80:1245-1250.

3. Ellram, A., Horgan, B., and Hulke, B. 2007. Mowing strategies and dew removal to minimize dollar spot on creeping bentgrass. Crop Sci. 47:2129-2137.

4. Goatley, J. L., and Lewis, R. W. 1966. Composition of guttation fluid from rye, wheat, and barley seedlings. Plant Physiol. 41:373-375.

5. Huber, L., and Gillespie, T. J. 1992. Modeling leaf wetness in relation to plant disease epidemiology. Annu. Rev. Phytopathol. 30:533-577.

6. Jackson, N., and Howard, F. L. 1966. Fungi as agents of turfgrass disease. J. Sports Turf Res. Inst. 42:9-16.

7. Landschoot, P. J., and McNitt, A. S. 1997. Effect of nitrogen fertilizers on suppression of dollar spot disease of Agrostis stolonifera L. Int. Turfgrass Soc. Res. J. 8:905-911.

8. McDonald, S. J., Dernoeden, P. H., and Bigelow, C. A. 2006. Dollar spot and gray leaf spot severity as influenced by irrigation, chlorothalonil, paclobutrazol, and a wetting agent. Crop Sci. 46:2675-2684.

9. McDonald, S. J., Dernoeden, P. H., and Bigelow, C. A. 2006. Dollar spot control in creeping bentgrass as influenced by fungicide spray volume and application timing. Appl. Turfgrass Sci. Online publication. doi:10.1094/ ATS-2006-0531-01-RS.

10. Pigati, R. L., Dernoeden, P. H., Grybauskas, A. P., and Momen, B. 2010 Simulated rainfall and mowing impact fungicide performance when targeting dollar spot in creeping bentgrass. Plant Dis. 94:596-603.

11. Putman, A. I. 2008. Influence of cultural and chemical management practices on dollar spot severity and Sclerotinia homeocarpa sensitivity to fungicides. M.S. thesis, University of Connecticut, Storrs.

12. Williams, D. W., and Powell, A. J. 1995. Dew removal and dollar spot on creeping bentgrass. Golf Course Manage. 63:49-52.

13. Williams, D. W., Powell, A. J., Dougherty, C. T., and Vincelli, P. 1998 Separation and quantification of the sources of dew on creeping bentgrass. Crop Sci. 38:1613-1617.

14. Williams, D. W., Powell, A. J., Vincelli, P., and Dougherty, C. T. 1996 Dollar spot on bentgrass influenced by displacement of leaf surface moisture, nitrogen, and clipping removal. Crop Sci. 36:1304-1309. 